\title{
PARTICIPATION OF A SPECIALIST WHEN PLANNING INVESTIGATION OF A CRIME
}

\section{Yaremchuk V.O.}

Investigation of criminal offences is often frequently accompanied by involvement of informed persons which help the investigator to establish and investigate the important circumstances. The essential help to the investigator is given by different specialists who are involved from state and private institutions, enterprises, organizations. However, today in the criminalistic literature the forms of the specialist help in details in planning of carrying out investigative (search) actions, covert investigative (search) actions are not revealed. The aim of the paper is determination of a specialist participation in planning crime investigation. When involving a specialist in planning investigative (search) action, an investigator clarifies himself: 1) with the form of the help of the expert which will be given when organizing of carrying out investigative (search) action; 2) with a speciality of the necessary specialist, and also from what institution, enterprise or organization one has to involve the specialist or the specialist who does not work in such institutions (sculptor, artist, hunter and others); 3) depending on a type of a criminal offence, on the need of simultaneous use of different kinds of special knowledge, on complexity of carrying out investigative (search) action itself or covert investigative (search) action whether it's necessary to receive the help of several specialists. It's possible to distinguish advisory, analytical, organizational, technical, reference, preparatory forms of the specialist help at his participation in planning of carrying out investigative (search) or covert investigative (search) action. Forms of the specialist help depend on a type of a criminal offence. It's necessary to take into account the specificity in carrying out certain investigative (search) or covert investigative (search) action. Sometimes it's expedient for an investigator to receive the help of several specialists when organizing carrying out such separate actions.

Keywords: organization and planning of crime investigation, specialist, special knowledge, investigative (search) actions, covert investigative (search) actions.

O. I. Резнікова, асистент кафедри кримінального процесу та оперативно-розшукової діяльності Національного юридичного університету імені Ярослава Мудрого, кандидат юридичних наук

\section{ЩОДО КРИМІНАЛІСТИЧНОГО РОЗУМІННЯ ЗЛОЧИНІВ КОРУПЦІЙНОЇ СПРЯМОВАНОСТІ}

Проаналізовано чинне кримінальне та антикорупційне законодавство України. Виявлено розбіжності стосовно правового регулювання настання кримінальної відповідальності за корупційні й пов'язані з корупцією злочини, окреслено иляхи їх усунення. Доведено необхідність застосування діяльнісного підходу щцодо криміналістичного розуміння злочинів корупційної спрямованості.

Ключові слова: корупція; злочини корупційної спрямованості; корупџійні злочини; злочини, пов'язані з корупџією; злочинна корупџійна діяльність. 
Негативні економічні, політичні та соціальні чинники, низький рівень правової свідомості й культури громадян України сприяють поширенню на іiї теренах такого руйнівного соціального явища, як корупщія. Масштаби поширення й негативні наслідки надали їй статус «загрози національній безпеці та інтересам України» ${ }^{1}$, що закономірно, адже корупція здатна спричинити серйозні проблеми в розвитку суспільства й держави, посягати на зовнішню та внутрішню безпеку, економічний добробут, демократичні інститути й цінності, порушити принципи справедливості, верховенства права, належного управління та рівності, провокувати розвиток організованої й економічної злочинності², перешкоджати ефективному використанню ресурсів, надавати недемократичні способи утримання влади ${ }^{3}$.

Масштабне поширення корупції в Україні підтверджують дані як міжнародних рейтингів, так і національних звітів. Так, Індекс сприйняття корупції (Corruption Perception Index, далі - CPI) міжнародної організації Transparency International Україна вказує на стабільно високий рівень корупції в Україні. Так, за CPI-2016 серед 176 країн світу наша держава посіла 131-ше місце, набравши лише 29 балів із 100. Цю позицію з Україною поділяють Казахстан, Росія, Непал та Іран ${ }^{4}$. Для порівняння за СРІ-2015 Україна серед 168 країн світу посідала 130-те місце з 27 балами, а роком раніше 142-гу позицію серед 175 країн із 26 балами 5 . На думку фахівців ТІ Україна, покращенню позицій України за СРІ сприяло просування антикорупційної реформи, яка, однак, через відсутність дієвої судової системи та фактичну безкарність корупціонерів не дає Україні подолати 30-бальний бар'єр, що $є$ «ганьбою для нації». Тобто показники України за СРI $є$ недостатніми для країни, де боротьба з корупцією - головний пріоритет влади ${ }^{6}$.

Звіти про стан протидії корупції в Україні за період 2013-2016 рр., як не дивно, демонструють дещо інші показники. Так, якщо звернутися до вітчизняних статистичних даних, то за три роки кількість кримінальних проваджень за ознаками корупції, у яких було розпочато (продовжених) досудове розслідування, зменшилася на 69,6 \% (із 3277 до 2281 проваджень). Цікаво, що з обвинувальним актом або клопотанням про застосування

1 Про основи національної безпеки України: Закон України від 19.06.2003 № 964-IV. URL: http://zakon2.rada.gov.ua/laws/show/964-15 (дата звернення: 09.07.2017).

2 Конвенція Організації Об'єднаних Націй проти корупції: Закон України від 18.10.2006 № 251-V. URL: http://zakon5.rada.gov.ua/laws/ show/995_c16 (дата звернення: 09.07.2017).

3 Фукуяма Ф. Що таке корупція (переклад М. Мишкала). Інформаційно-аналітичний портал «Хвиля». URL: http://hvylya.net/analytics/society/frensis-fukuyama-shhotake-koruptsiya.html (дата звернення: 09.07.2017).

4 Індекс корупції CPI-2016. Transparency International Україна. URL: http://tiukraine.org/research/ indeks-koruptsiyi-cpi-2016/ (дата звернення: 09.07.2017).

5 Подъем с глубины: Украина 130-я в Индексе восприятия коррупции. Transparency International Украина. 2016. URL: http://ti-ukraine.org/news/mediaaboutus/5763html (дата звернення: 09.07.2017).

6 Індекс корупції CPI-2016. Transparency International Україна. 
примусових заходів медичного характеру до суду щороку спрямовується близько 60 \% кримінальних проваджень (1605 і 1739 відповідно). До того ж, із 2013 р. скоротилася кількість закритих кримінальних проваджень - із 452 до 7 проваджень у 2016 р. (у 65 разів). Разом із цим кількість виправданих і осіб, щодо яких провадження закрито за відсутністю події або складу кримінального правопорушення чи за не доведенням винуватості, склала 6 i 64 особи, тобто показник зріс у 10 разів ${ }^{1}$. Такі дані породжують багато питань, відповіді на які невзмозі задовольнити ні пересічних громадян, ні фахівців.

Отже, майже щоденні численні резонансні викриття й затримання осіб за підозрою у вчиненні злочинів корупційної спрямованості в поєднанні 3 незначним відсотком обвинувальних вироків, особливо в кримінальних провадженнях щодо «топ-корупції», відкрите протистояння між правоохоронними органами, до компетенції яких належить виявлення й розслідування злочинів корупційної спрямованості, маніпулювання такою засадою кримінального провадження, як змагальність (ст. 22 КПК України), що, подекуди, набуває вигляду відкритої протидії професійній діяльності як сторони обвинувачення, так і сторони захисту, невідповідність строків досудових розслідувань і судових розглядів вимозі розумності (ст. 28 КПК України), а також інші несприятливі чинники, детермінують укорінення у свідомості українців терпимості до корупції, адже, як максимум, - спричиняють у громадян сприйняття правоохоронної та судової системи як заангажованої й корумпованої або, як мінімум, - дозволяють констатувати їх безпорадність перед цим загрозливим явищем.

Потреба протидії корупції зумовлює необхідність консолідації зусиль державних і місцевих органів влади, їх службових і посадових осіб, національних і міжнародних організацій, представників громадськості та науки, імплементації провідного антикорупційного досвіду. Триваюча антикорупційна реформа в Україні призводить до стрімкого оновлення матеріального та процесуального законодавства, створення нових антикорупційних органів (Національного агентства з питань запобігання корупції, Національного антикорупційного бюро України, Спеціалізованої антикорупційної прокуратури, а в майбутньому - Вищого антикорупційного суду), перерозподілу компетенції вже існуючих, що не завжди спричиняє позитивні правозастосовні наслідки, тому переконує у важливості наукового забезпечення протидії корупції ${ }^{2}$, яка є багатовекторною діяльністю. Це підтверджує й актуальність дослідження проблеми криміналістичного забезпе-

1 Індекс корупції CPI-2016. Transparency International Україна.

2 М. В. Киричко, аналізуючи законодавчі зміни до КК України, викликані антикорупційною реформою, зауважив, що одночасно можна побачити: 1) вади законодавчої техніки; 2) науково необгрунтовані новели; 3) поняття без законодавчого визначення; 4) ${ }^{\circ}$ відсутність ясності стосовно окремих складів злочинів і особливо щодо співвідношення нових норм із тими, які були в КК України та викладені в новій редакції (див.: Киричко М. В. Кримінальна відповідальність за корупцію. Харків: Право, 2013. С. 7). 
чення розслідування злочинів корупційної спрямованості та формування власне їх криміналістичного розуміння. Так, ідеться про побудову новітньої криміналістичної класифікацї̈ зазначеної групи злочинів, адже вона є основою побудови криміналістичної характеристики злочинів корупційної спрямованості та системи методик їх розслідування: простих (видових, підвидових мікрометодик) і ускладнених (родових, міжродових, комплексних) методик ${ }^{1}$. Метою статті є спроба запропонувати підходи до криміналістичного розуміння злочинів корупційної спрямованості, визначити напрями пошуку науково-практичних засад їх класифікації.

Вагомий внесок у розроблення теоретичних засад формування криміналістичних методик і криміналістичної класифікації злочинів зробили такі вчені-криміналісти, як А. Ф. Волобуєв, В. К. Гавло, В. І. Галаган, І. Ф. Герасимов, В. А. Журавель, А. В. Іщенко, О. Н. Колесніченко, В. О. Коновалова, Г. А. Матусовський, В. О. Образцов, М. В. Салтевський, В. В. Тіщенко, В. Ю. Шепітько, Б. В. Щур та ін. Наукова спільнота достатньо тривалий час здійснює дослідження питань криміналістичного забезпечення розслідування злочинів корупційної спрямованості та проблем побудови окремих методик розслідування злочинів цієї групи, зусиллями таких учених, як В. А. Журавель, В. П. Корж, Я. С. Мишков, В. М. Трепак, В. Ю. Шепітько та ін. Проте підходи до криміналістичного розуміння злочинів корупційної спрямованості та методик їх розслідування дотепер не позбавлені дискусійності, що, в контексті постійних змін антикорупційного законодавства України, посилює актуальність їх комплексного наукового пізнання. Такий науковий пошук має спиратися й на наукові досягнення фахівців із кримінального права та кримінального процесу: Ю. В. Бауліна, В. І. Борисова, Ю. М. Грошевого, О. О. Дудорова, О. В. Капліної, В. М. Киричка, В. Т. Нора, В. Я. Тація, М. І. Хавронюка, О. Г. Шило та ін.

Першочерговим завданням на шляху вирішення проблеми побудови системи методик розслідування злочинів корупційної спрямованості треба вважати формулювання власне криміналістичного розуміння злочинів цієї групи та побудова їх криміналістичної класифікації. Правовою підставою здійснення такої діяльності є норми КК України та положення Закону України «Про запобігання корупції» від 14.10.2014 № 1700-VII (далі - Закон № 1700-VII), які потребують ретельного осмислення не лише фахівцями в галузі кримінального права, а й криміналістики, адже слідчим, детективам, співробітникам оперативних підрозділів, прокурорам, суддям і адвокатам необхідні новітні та ефективні криміналістичні засоби, прийоми, методи й рекомендації щодо реалізації їх функцій і повноважень у цій сфері.

Офіційне визначення поняття корупиіï надає Закон № 1700-VII, де вказано, що це використання особою, зазначеною в ч. 1 ст. 3 цього Закону, наданих ӥй службових повноважень чи пов'язаних із ними можливостей із метою одержання неправомірної вигоди або прийняття такої вигоди чи прийняття обіцянки/пропозиції такої вигоди для себе чи інших осіб або

1 Журавель В. А. Криміналістичні методики: сучасні наукові концепції: монографія. Харків: Апостіль, 2012. С. 92-94. 
відповідно обіцянка/пропозиція чи надання неправомірної вигоди особі, зазначеній у ч. 1 ст. 3 цього Закону, або на ії вимогу іншим фізичним чи юридичним особам із метою схилити цю особу до протиправного використання наданих ӥй службових повноважень або пов'язаних із ними можливостей ${ }^{1} .3$ огляду на таке визначення, учені виокремлюють такі форми корупції: використання службових повноважень/пов'язаних із ними можливостей особами із метою одержання неправомірної вигоди; прийняття неправомірної вигоди, прийняття іії обіцянки/пропозиції особами для себе/ інших осіб; обіцянка/пропозиція чи надання неправомірної вигоди особам, зазначеним у ст. 3 Закону № 1700-VII, або на їх вимогу іншим фізичним/ юридичним особам із метою схилити цих осіб до протиправного використання службових повноважень/пов'язаних із ними можливостей ${ }^{2}$.

Похідним від поняття «корупція» $€$ поняття «корупційне правопорушення», яке визначається як діяння, що містить ознаки корупції, за які законом перебачено настання кримінальної, дисциплінарної та/або цивільно-правової відповідальності. Разом із тим, законодавець використовує й такий термін, як «правопорушення, пов'язані з корупцією», яким позначає діяння, що не містять ознак корупції, але порушують вимоги, заборони та обмеження, що містяться в Законі № 1700-VII, за вчинення яких передбачена кримінальна, дисциплінарна, цивільно-правова та/або адміністративна відповідальність ${ }^{3}$.

Отже, корупція як негативне явище реальної дійсності безпосередньо об'єктивується в різних корупційних правопорушеннях, за вчинення яких передбачена кримінальна, адміністративна, цивільно-правова та дисциплінарна відповідальність. Тому законодавче визнання поняття корупції має вирішальне значення для встановлення кола таких діянь, адже ії ознаки входять до ознак складу корупційного правопорушення. Визначення поняття корупції є міжгалузевим, юридичне значення якого полягає в тому, що в разі встановлення його ознак у певному правопорушенні воно визнається «корупційним», а особа притягається до певного виду юридичної відповідальності. До такої особи застосовуються додаткові обмеження й правової наслідки, передбачені Законом № 1700-VII ${ }^{4}$ та іншими нормативноправовими актами 5 .

1 Про запобігання корупції: Закон України від 14.10.2014 № 1700-VII. URL: http://zakon0.rada.gov.ua/laws/show/1700-18/page (дата звернення: 16.07.2017).

2 Настільна книга детектива, прокурора, судді: коментар антикорупційного законодавства/за ред. М. І. Хавронюка. Київ: ВД «Дакор», 2016. С. 12.

3 Про запобігання корупції: Закон України від 14.10.2014 № 1700-VII.

4 Киричко М. В. Зазнач. твір. С. 12.

5 До спеціальних правових наслідків учинення корупційного правопорушення відносять: спеціальну конфіскацію майна, одержаного внаслідок учинення таких правопорушень (статті 961-96² КК України); застосування до юридичних осіб заходів, передбачених статтями $96^{3}-96^{11}$ КК України; настання адміністративної відповідальності за ст. $172^{9}$ КУПАП; відомості про фізичних осіб, які вчинили корупційне або пов'язане $з$ корупцією правопорушення, а також про юридичних осіб, щодо яких застосовано заходи кримінально-правового характеру у зв'язку з учиненням коруп- 
Найбільш небезпечними серед усіх корупційних проявів $є$ кримінально карані діяння, які в літературі називають по-різному: «корупційні злочини», «злочини корупційної спрямованості» або «злочини, пов'язані з корупцією» ${ }^{1}$. Зауважимо, що до початку антикорупційної реформи національне законодавство не згадувало жоден із зазначених термінів, а вчені, спираючись на законодавче визнання поняття корупції, намагались самостійно з'ясувати, які ж саме склади кримінально караних суспільно небезпечних діянь, передбачених КК України, доцільно відносити до досліджуваної групи злочинів, що, однак, набувало статусу наукових дискусій, покласти край яким могли законодавчі зміни наприкінці 2014 р. Із прийняттям Закону України «Про Національне антикорупційне бюро України» від 14.10.2014 № 1698-VII ${ }^{2}$ і внесенням змін до КК України, в останньому з'явився офіційний термін «корупційні злочини» ${ }^{3}$. Зокрема, у примітці до ст. 45 «Звільнення від кримінальної відповідальності у зв'язку з дійовим каяттям» КК України встановлюється, що корупційними злочинами вважаються злочини, передбачені статтями 191, 262, 308, 312, 313, 320, 357, 410 КК України (у разі вчинення шляхом зловживання службовим становищем), і злочини, передбачені статтями $210,354,364,364^{1}, 365^{2}, 368-369^{2}$ КК України. Отже, законодавчий перелік корупційних злочинів був сформований шляхом простого перерахування 19 складів злочинів, та $€$ вичерпним ${ }^{4}$. Разом із тим, до групи корупційних злочинів увійшли склади кримінально караних діянь, що істотно різняться між собою за об'єктом злочинного посягання. Ідеться про злочини проти власності, у сфері господарської діяльності, проти громадської безпеки, у сфері обігу наркотичних засобів, психотропних речовин, їх аналогів або прекурсорів та інші злочини проти здоров'я населення, проти авторитету органів державної влади, органів місцевого самоврядування, об’єднань громадян і злочини проти журналістів, у сфері службової діяль-

ційного правопорушення, уносяться до Єдиного державного реєстру осіб, які вчинили корупційні або пов’язані з корупцією правопорушення (ст. 59 Закону № 1700VII); позбавлення права обіймати певні посади або займатися певною діяльністю, пов'язаними 3 виконанням функцій держави або місцевого самоврядування, або такої, що прирівнюється до цієї діяльності (ст. 65 Закону № 1700-VII). Окремими законами передбачені спеціальні правові наслідки притягнення особи до відповідальності за корупційні правопорушення, зокрема, наслідки, що стосуються: призначення на певні посади, виконання обов'язків; дисциплінарної відповідальності (ч. 2 ст. 65 Закону № 1700-VII); пенсійного забезпечення (див.: Настільна книга детектива, прокурора, судді. С. 20).

1 Шепітько В. Ю., Журавель В. А. Розслідування злочинів корупційної спрямованості: наук.-практ. посіб. Харків: Харків юрид., 2013. С. 10.

2 Про Національне антикорупційне бюро України: Закон України від 14.10.2014 № 1698-VII. URL: http://zakon3.rada.gov.ua/laws/show/1698-18 (дата звернення: 19.07.2017).

3 Мисливий В. А. Протидія корупції : кримінально-правовий аспект. Кримінально-правові та кримінологічні засади протидї̈ корупції: зб. матеріалів III міжнар. наук.-практ. конф. (3 квіт. 2015 р.). Харків: Золота миля, 2015. С. 121.

4 Савченко A. B. Корупційні злочини (кримінально-правова характеристика): навч. посіб. Київ: Центр учб. літ., 2016. С. 15. 
ності та професійної діяльності, пов'язаної з наданням публічних послуг; проти встановленого порядку несення військової служби (військові злочини) КК України.

Зазначені норми КК України та Закону № 1700-VII щодо формування криміналістичного розуміння злочинів корупційної спрямованості дають змогу висловити такі міркування.

По-перше, виникає питання щодо законодавчої техніки, використаної в ст. 45 КК України. Так, В. А. Мисливий зауважує, що закріплення переліку корупційних злочинів у нормі Загальної частини КК України, присвяченій звільненню від кримінальної відповідальності, виглядає штучно. Учений пропонує перемістити цей перелік у розділ, присвячений злочинам у сфері службової й професійної діяльності, пов'язаної з наданням публічних послуг, адже ним охоплюється більшість корупційних злочинів ${ }^{1}$. Однак А. В. Савченко наголошує, що специфіка КК України полягає в тому, що він не містить окремий розділ, присвячений корупційним злочинам. Визначення корупційних злочинів у примітці до ст. 45 КК України зумовлено тим, що в ній уперше згадується термін «корупційний злочин»².

На нашу думку, доцільніше виокремити систему норм у спеціально створеному розділі КК України, де передбачити визначення поняття злочинів корупційної спрямованості, їх видів (корупційних і пов'язаних із корупцією; умовних і безумовних), закріпити їх перелік. Ця пропозиція обгрунтовується тим, що, проаналізувавши КК України та Закон № 1700VII, можемо стверджувати про існування розбіжностей у підходах до визначення видів корупційних кримінально караних діянь. Так, у першому йдеться лише про «корупційні злочини», натомість другий заклав значно ширшу концепцію, указавши на існування двох видів кримінально караних суспільно небезпечних діянь, за вчинення яких може наставати кримінальна відповідальність - корупційних і пов'язаних із корупцією. 3 огляду на це, пропонуємо уніфікувати їх положення та передбачити в КК України дві підгрупи злочинів - корупційних і пов'язаних із корупцією, а як родовий стосовно цих понять використовувати термін «злочини корупційної спрямованості».

У цьому контексті слушним є зауваження В. М. Киричка, який зазначає, що корупційні злочини - це передбачені КК України умисні діяння, які містять не лише ознаки відповідного складу злочину, а й ознаки корупції. У процесі застосування КК України, правоохоронцям необхідно встановлювати дві системи ознак у діянні, із кожною з яких пов'язані певні правові наслідки: склад злочину за КК Украӥни (підстава кримінальної відповідальності) та склад корупиійного правопорушення (підстава наслідків, передбачених у Законі № 1700-VII) (курсив наш - O. P.)․․ Таку позицію науковець висловив ще до закріплення переліку корупційних злочинів у КК України, проте, коли взяти до уваги, що останній сформульований недо-

\footnotetext{
Мисливий В. А. Зазнач. твір. С. 124.

Савченко А. В. Зазнач. твір. С. 13.

Киричко М. В. Зазнач. твір. С. 14.
} 
статньо повно, про що буде йтися далі, то запропонований підхід убачається слушним.

Підгрунтям формування групи корупційних злочинів пропонуємо вважати істотні ознаки поняття «корупція» (Закон № 1700-VII), а під час вирішення такого питання кожен склад кримінально караного суспільно небезпечного діяння має піддаватися аналізу для встановлення наявності/ відсутності таких ознак. Натомість, формування групи злочинів, пов'язаних iз корупцією, має відбуватися шляхом констатації відсутності в складах таких кримінально караних суспільно небезпечних діянь ознак корупції, проте наявності порушень вимог, заборон і обмежень, передбачених Законом № 1700-VII. Цей підхід дозволить уніфікувати положення КК України відповідно до концепції Закону № 1700-VII, а також, на відміну від існуючого, сформувати якісний перелік не лише корупційних, а й пов'язаних із корупцією злочинів.

Законодавче визнання злочину корупційним або пов'язаним із корупцією виключатиме необхідність змінювати перелік обставин, які підлягають доказуванню в кримінальному провадженні (ст. 91 КПК України), тобто не буде жодної необхідності до такого переліку обставин включати «ознаки корупції» або вказівку на «порушення вимог, заборон та обмежень Закону № 1700-VII». Те саме стосується й пропозицій щодо внесення змін до ст. 368 КПК України - уключення питання про визнання діяння корупційним до питань, які віршується судом при ухвалені вироку, адже вказаним презюмується наявність/відсутність у складах злочинів ознак корупції або порушень вимог, заборон, обмежень Закону № 1700-VII ${ }^{1}$.

По-друге, щодо самого переліку корупційних злочинів, передбаченого в КК України, зауважимо, що останній дійсно викликає багато питань, зокрема, незрозумілими залишилися критерії формування такої групи злочинів. Із цього приводу М. І. Хавронюк зауважує, що перелік корупційних злочинів КК України не збігається з підслідністю, установленою для спеціальних антикорупційних органів, зокрема НАБУ (ст. 216 КПК України), $\epsilon$ неповним і неточним. Головна його вада - суперечність поняттю корупційного правопорушення. Зокрема, учений указує, що корупційними, крім визначених статтями $364,364^{1}, 365^{2}, 368,368^{3}, 368^{4}, 369,369^{2}$ і $369^{3}$ КК України, треба було б визначити й діяння, передбачені статтями 189 і $206^{2}$ КК України, якщо їх учинено службовою особою з використанням службового становища; злочини, де службова особа є спеціальним суб'єктом простого чи кваліфікованого складу (статті 132, 137, 145, 148 КК України та ін.), за умови їх учинення з метою одержання неправомірної вигоди для себе чи третіх осіб. Разом із тим корупційними не можуть бути діяння, передбачені статтями 210 і 320 КК України ${ }^{2} .3$ огляду на зазначене, М. І. Хавронюк запропонував вести мову про: власне корупційні злочини (примітка до ст. 45 КК України); злочини, передбачені ст. $369^{3}$ КК України, які через особливості суб' єктивного складу невизнані корупційними; злочини, які за певних

1 Киричко М. В. Зазнач. твір. С. 14.

2 Настільна книга детектива, прокурора, судді. С. 22, 26. 
умов можуть бути визнані корупційними; квазікорупційні злочини - злочини, пов'язані з корупцією1.

На сторінках юридичної літератури висловлюються й інші зауваження 3 приводу переліку корупційних злочинів у чинному КК України. Так, наголошується, що злочини, передбачені статтями 262, 308, 312, 313, 320, 357 КК України, не можуть бути віднесеними до числа корупційних, адже останні, за своєю правовою природою, не містять ознак корупції (Закон № 1700VI), хоча й можуть супроводжувати корупційні злочини. До корупційних злочинів учені пропонують відносити злочини, передбачені ч. 2 ст. 191, статтями $354,364^{1}, 365,365^{2}, 368,368^{2}, 368^{3}, 368^{4}, 369,369^{2}, 423$ КК України ${ }^{2}$.

Слушною вважається й позиція В. Ю. Шепітька та В. А. Журавля стосовно корупційних злочинів, висловлена до офіційного визначення цього поняття в КК України. Так, на думку вчених, корупційні злочини (злочини корупційної спрямованості) - це збірне поняття, що включає в себе злочини, передбачені статтями $191,364,364^{1}, 365,365^{2}, 366,367,368,368^{2}, 368^{3}, 368^{4}$, $369,370,375,376$ КК України та ін. ${ }^{3}$ Учені запропонували такий перелік на основі аналізу чинного на той час Закону України від 07.04.2011 № 3206-VI «Про засади запобігання і протидії корупції», що вбачається правильним.

В аналізованому контексті дещо інакше виглядають положення звітів про стан протидії корупції в Україні, які містять перелік «кримінальних корупційних правопорушень» ${ }^{4}$. Цей перелік не відповідає переліку, що міститься в ст. 45 КК України, порівняно з останнім, $є$ значно розширеним i, чомусь, не охоплює всіх складів злочинів, передбачених у ній як корупційні. Така форма статистичного обліку ведеться відповідно до Інструкції про порядок обліку кримінальних та адміністративних корупційних правопорушень від 22.04.2013. Так, згідно з п. 3.8.1 при складанні окремих показників форми № 1-КОР (звіт про стан протидії корупції в Україні) «обліку підлягають лише ті кримінальні правопорушення, що містять ознаки корупції» $\rangle^{5}$.

Отже, критерії віднесення тих чи інших складів злочинів до сучасного переліку корупційних (ст. 45 КК України) є неоднозначними. Так, критерії зарахування законодавцем до числа «безумовно» корупційних злочинів

1 Настільна книга детектива, прокурора, судді. С. 21, 28.

2 Антикорупційні засади діяльності органів влади: наук.-практ. посіб./за заг. наук. ред. А. В. Роздабіди. 2-ге вид., переробл. і допов. Харків: ТОВ «ДРУКАРНЯ МАДРИД», 2014. С. 198, 201.

Шепітько В. Ю., Журавель В. А. Зазнач. твір. С. 11-12.

4 Серед яких: ч. 2-4 ст. 189 , ч. 2-5 ст. 191, ч. 3 ст. 206 , ст. 232, ч. 2, 3 ст. 262 , ст. 353 , ч. 2,3 ст. 358 , статті $364,364^{1}, 365,365^{1}, 365^{2}$, ч. 2 ст. 366 , статті $368,368^{2}$, $368^{3}, 368^{4}, 369^{2}, 370$, ч. 2 ст. 375 , ч. 2,3 ст. 410 , ст. 423 , ч. 1,3 ст. 424 КК України та «інші корупційні правопорушення» (див.: звіти про стан протидії корупції за 12 місяців 2013, 2014, 2015 та 2016 років. Міністерство внутрішніх справ України. 2016. URL: http://mvs.gov.ua (дата звернення: 09.07.2017).

5 Інструкція про порядок обліку кримінальних та адміністративних корупційних правопорушень: наказ Ген. прокуратури, МВС, СБУ, М-ва доходів і зборів, М-ва оборони, Держ. суд. адміністрації України від 22.04.2013 № 52/394/172/71/268/60. URL: http://pp.ck.court.gov.ua/userfiles/Korupciya.pdf (дата звернення: 16.07.2017). 
певних складів кримінально караних діянь законодавцем прямо не названі. Сдиною прямо названою ознакою корупційних злочинів у КК України є вчинення певних із них шляхом зловживання службовим становищем. Саме така ознака названа для обмежено або умовно корупційних злочинів ${ }^{1}$. На нашу думку, підгрунтями формування групи корупційних злочинів повинні були стати істотні ознаки корупції, передбачені в Законі № 1700-VII. Так, серед останніх учені виокремлюють, з одного боку, протиправне використання службових повноважень чи пов'язаних із ними можливостей (форма діяння); неправомірну вигоду (може бути предметом, засобом або метою), а $з$ другого - обіцянку/пропозицію чи надання неправомірної вигоди (форма діяння або його предмет); використання службових повноважень і відповідних можливостей (мета) ${ }^{2}$. Такі ознаки дозволяють говорити про наявність певних форм корупції, тому вони повинні стати орієнтиром у формуванні переліку корупційних злочинів.

Разом із тим у Законі № 1700-VII ідеться про таку ознаку корупції, як «використання службових повноважень чи пов'язаних із ними можливостей». Натомість КК України взагалі не згадує про вчинення злочинів шляхом «використання можливостей», пов’язаних із владою, службовим становищем чи службовими повноваженнями, на що вказує Закон № 1700-VII. Виходячи 3 принципу законності (ст. 3 КК України), використання зазначених можливостей не може бути ознакою складу злочину ${ }^{3}$. Із приводу «зловживання службовим становищем» як ознаки умовно корупційних злочинів, у літературі слушно наголошується на тому, що в КК України передбачено ряд злочинів, які можуть учинятися, зокрема, шляхом: «використання службового становища», «використання влади або службового становища», «використання наданих повноважень», «використання становища, яке займає працівник на підприємстві, в установі чи організації», «використання свого становища, наданих повноважень, влади, службового становища» тощо, тобто на використання різних словосполучень на позначення діяння ${ }^{4}$.

Отже, уявляється, що законодавець склав неповний перелік корупційних злочинів і діяв дещо вибірково. Так, проаналізувавши групу обмежено корупційних злочинів, склалося враження, що вона була утворена шляхом формального відшукання в нормах КК України формулювання «вчинення певних злочинних діянь шляхом зловживання службовим становищем», інакше неможливо логічно пояснити, чому інші кримінально карані діяння, які підпадають під ознаки корупції та вчиняються шляхом, наприклад, «використання владних повноважень», «використання наданих повноважень», «використання влади або службового становища» та інші, не ввійшли до цього переліку. Деякі злочини, які можуть учинятися шляхом «використан-

Мисливий В. А. Зазнач. твір. С. 124.

Настільна книга детектива, прокурора, судді. С. 14-15.

Там само.

4 Терміни «використання влади» та «використання службового становища» співвідносяться як синоніми. Представник влади, використовуючи публічну владу, одночасно використовує своє службове становище представника влади; в інших випадках він використовує лише своє службове становище. 
ня службового становища», також не увійшли до переліку корупційних ${ }^{1}$. Це ж стосується складів злочинів, що не містять вказівки на спеціального суб'єкта їх учинення та спосіб його дій, але з диспозиції норми яких прямо випливає, що останні можуть бути вчинені лише службовою особою шляхом зловживання службовим становищем або владою (статті 319, 371, 372 та ін. КК України $)^{2}$. Невідома й доля деяких «класичних» корупційних або пов'язаних із корупцією злочинів, наприклад, протиправний вплив на результати офіційних спортивних змагань (ст. $369^{3}$ КК України) та ін. У деяких випадках, необачно прирівняні до корупційних злочини, які лише пов'язані 3 корупцією․ Убачається, що саме відсутність чітких критеріїв формування цієї групи кримінально караних діянь слугувала причиною застосування принципу вибірковості під час іiї змістовного наповнення.

Із позиції практики виявлення та розслідування кримінально караної корупції, а також її наукового супроводження криміналістичними рекомендаціями, привабливим убачається застосування широкого підходу, а отже, оперування запропонованою теоретичною конструкцією «злочини корупційної спрямованості». Остання здатна слугувати плідним фундаментом для побудови практично орієнтованої криміналістичної класифікації таких злочинів, розроблення якої важливе з огляду на вирішення проблеми побудови системи криміналістичних методик розслідування злочинів корупційної спрямованості та формування теоретичних основ і науково-практичних рекомендацій, присвячених криміналістичному забезпеченню розслідування таких злочинів.

У повсякденній діяльності правоохоронних органів учинення одного корупційного або пов'язаного з корупцією правопорушення, у тому числі злочину, $є$ рідкісним явищем. Сучасна корупція, завдяки ії визначенню в Законі № 1700-VII у широкому значенні, як правило, об’єктивується в певній деліктній діяльності особи або їх групи. Так, із метою досягнення певного протиправного результату особа (іх група) може (можуть) учинити сукупність як власне корупційних, так і пов'язаних з корупцією правопорушень. Такі правопорушення пов'язані між собою і $є$ причиною або наслідком один одного. Саме тому пропонуємо під час дослідження кримінально караної корупції виходити не лише 3 поділу злочинів корупційної спрямованості на корупційні та пов'язані з корупцією, а й із необхідності застосування діяльнісного підходу в пізнанні цього явища, а отже, прагнути до вивчення проблематики на рівні окремого виду злочинної діяльності - корупційної. Із цього приводу слушним убачається зауваження В. В. Тіщенка, що в структурі сучасної злочинності дедалі більше місця займає не масив одиничних

1 Наприклад, ч. 2,3 ст. 149 , ч. 3,4 ст. 157 , ч. 4 ст. 158 , ч. 2 ст. $158^{2}$, ч. 2 ст. 169 , ч. 3 ст. 206 , ч. 3 ст. $206^{2}$, ч. 2 ст. $258^{4}$, ч. 3 ст. $298^{1}$, ч. 2,3 ст. 332 , ч. 2 ст. 343 , ч. 2 ст. 344 , ст. 354 , ч. 2 ст. 447 КК України (за умови їх учинення з метою одержання неправомірної вигоди).

2 Кримінальний кодекс України: наук.-практ. коментар у 2 т. Т. 2: Особлива частина/Ю. В. Баулін, В. І. Борисов, В. І. Тютюгін та ін. 5-те вид., допов. Харків: Право, 2013. 1040 с.

3 Настільна книга детектива, прокурора, судді. С. 15. 
злочинів, а сукупності злочинів тієї чи іншої спрямованості, що надає їм характер кримінального промислу - злочинної діяльності ${ }^{1}$.

Злочинна корупційна діяльність - об'єкт наукового пізнання криміналістики, а дослідження закономірностей розвитку такої діяльності та діяльності, пов'язаної з їі виявленням і розслідуванням, як досить самостійної підгрупи закономірностей, входять до предмета пізнання цієї галузі знань. Зауважимо, що поняття «злочинна корупційна діяльність», на нашу думку, ширше за поняття «злочини корупційної спрямованості», адже останнім охоплюється лише корупційні та пов'язані з корупцією злочини, натомість першим терміном, у криміналістичних цілях, можуть охоплюватися й інші злочини. Зокрема, може йтися про комплекс злочинів, а саме: базові злочини, тобто основний спосіб досягнення певної злочинної мети, що включає один чи декілька близьких, взаємопов'язаних злочинних діянь, передбачених КК України; допоміжні злочини, що забезпечують підготовку до вчинення та приховування базових злочинів корупційної діяльності, у тому числі їх слідів; побічні злочини, які виходять за межі «необхідного» для досягнення основної мети певного виду злочинної корупційної діяльності; нетипові злочини вчиняються корупціонером або їх групою, організованою групою або злочинною організацією, під впливом непередбачуваних обставин реальної дійсності, як реакція на зміну обстановки злочинної корупційної діяльності .

Отже, сьогодні необхідним є введення до КК України узагальнюючої категорії «злочини корупційної спрямованості» та виокремлення двох самостійних підгруп у їі межах - корупційних і злочинів, пов'язаних із корупцією. Критерієм утворення першої підгрупи треба вважати істотні ознаки та форми корупції, а другої - заборони, обмеження та вимоги, передбачені Законом № 1700-VII. Запропонований підхід дозволить покращити якість антикорупційного кримінального законодавства України, підвищити ефективність досудового розслідування та судового розгляду таких злочинів. До внесення таких змін у КК України, виходячи з принципу верховенства права та його складової - правової визначеності, корупційними необхідно вважати лише злочини, передбачені в ст. 45 КК України, за вчинення яких до особи можуть застосовуватися наслідки, передбачені Законом № 1700-VII.

Із метою криміналістичного забезпечення розслідування кримінально караної корупції слід виходити не лише з поділу злочинів корупційної спрямованості на корупційні та пов'язані з корупцією, а, з урахуванням діяльнісного підходу, прагнути до вивчення аналізованої проблематики на рівні окремого виду злочинної діяльності - корупційної, яка включає не лише корупційні та пов'язані з корупцією злочини, як базові та допоміжні, а й інші побічні або нетипові злочини, учинені у межах такої злочинної діяльності.

1 Тищенко В. В. Злочинна діяльність як об'єкт криміналістики. Актуальні проблеми держави і права. Одеса: Юрид. літ., 2006. Вип. 27. С. 139.

2 Куликов В. И. Основы криминалистической теории организованной преступной деятельности. Ульяновск: Филиал МГУ, 1994. С. 40. 


\title{
О КРИМИНАЛИСТИЧЕСКОМ ПОНИМАНИИ ПРЕСТУПЛЕНИЙ КОРРУПЦИОННОЙ НАПРАВЛЕННОСТИ
}

\author{
Резникова Е. И.
}

Проанализировано действующее уголовное и антикоррупчионное законодательство Украины. Выявлены различия, касающиеся правового регулирования наступления уголовной ответственности за коррупционные и связанные с коррупцичей преступления, очерчены пути их устранения. Доказана необходимость применения деятельностного подхода при формировании криминалистического понимания преступлений коррупџионной направленности.

Ключевые слова: коррупция; преступления коррупционной направленности; коррупционные преступления; преступления, связанные с коррупщией; преступная коррупционная деятельность.

\section{ON THE CRIMINALISTIC UNDERSTANDING OF CORRUPTION DIRECTEDNESS CRIMES}

\section{Reznikova O. I.}

Analysis of international anti-corruption ratings and national statistical reports points to a consistently high level of corruption in Ukraine, and, consequently, the relevance of further scientific support for the activities of the subjects of the fight against corruption, in particular, in the field of criminalistic support for the investigation of corruption offenses. Such problematics has a multifaceted character and consists of separate directions, which already have been studied in a certain way on the pages of scientific literature. At the same time, the problems of the formation of namely criminalistic understanding of corruption directedness crimes and the construction of a new criminalistic classification of this group of crimes were not earlier subjected to the system analysis, since the latter is the basis for constructing of a criminalistic characteristics of corruption directed crimes and the system of techniques for their investigation: simple and complicated ones. In the paper, the author came to the conclusion that as of today there is a need to introduce a general category of "corruption directedness crimes" into the Criminal Code of Ukraine and to distinguish two independent subgroups within its limits - corruption crimes and crimes related with corruption. Criteria for the formation of the first subgroup should be considered the essential signs and forms of corruption, and for the second-the prohibitions, restrictions and requirements stipulated by the Law of Ukraine "On the Prevention of Corruption". The proposed approach will improve the quality of the anti-corruption criminal legislation of Ukraine, increase the effectiveness of pre-trial investigation and judicial consideration of such crimes. Before making such changes to the Criminal Code of Ukraine, proceeding from the rule of law and its constituent-legal certainty, it's necessary to consider under corruption only the crimes, provided by Art. 45 of this Code, for the commission of which the consequences, stipulated by the mentioned Law may be applied to the person.

Keywords: corruption; crimes of corruption directedness; corruption crimes; crimes related with corruption; criminal corruption activity. 